\title{
Effect on Self-directed Learning Abilities, Interpersonal Understanding, and Satisfaction with the class among University Students based in a Team-Project Lesson
}

\author{
Byoungwook Ahn', Sanghoon Lee ${ }^{2}$ \\ ${ }^{1}$ Assisstant Professor, Department of Leisure Marine Sports, Hanseo University, South Korea \\ ${ }^{2}$ Assisstant professor, Department Liberal Arts and Interdisciplinary Studies, Hanseo University, South Korea \\ 'bwahn75@hanseo.ac.kr, \\ ${ }^{2} 1$ sh8533@hanseo.ac.kr
}

\begin{abstract}
The purpose of this study is to establish the relationship between self-directed learning abilities, interpersonal understanding, and satisfaction of participants in team-based, focused classes. To achieve the purpose of this research, 409 university students who participate in team-based classes at a university located in South Korea were selected as candidates for the study. For data processing methods, we did frequency analysis, reliability analysis, and correlation analysis using SPSS 21.0 for Window, and used a structural equation model to verify the analysis of confirmatory factors and the theory of research using AMOS 18.0. Our findings were as follows. First, the self-directed learning ability of the teambased class participants affected interpersonal understanding. Second, the self-directed learning ability of team-based learning class participants affected satisfaction with the class. Third, the understanding of interpersonal relationships between team-based class participants affected the level of satisfaction with the class
\end{abstract}

Keywords : Self-directed learning abilities, Interpersonal understanding, Satisfaction with the class, Team-project lesson

\section{Byoungwook Ahn}

Assisstant Professor, Department of Leisure Marine Sports, Hanseo University, South Korea

bwahn75@hanseo.ac.kr,

\section{Introduction}

The government and universities are making great efforts to improve the quality of university education according to the social demands of strengthening competitiveness in university education. The Ministry of Education is demanding changes in the functions and roles of universities in response to social changes, such as the 4th Industrial Revolution [1]. The university is making various efforts, such as opening the results of lecture evaluation and applying new learning methods by organizing and operating related ministries for improving lecture skills. In other words, university education should provide students with an educational system that can generate knowledge, so that students can adapt to the future society and lead the future beyond the ability to transfer knowledge [2]. This means that the instructor-centered education system, which has been leading in the traditional education system, should be effectively improved to provide a creative education system [3]. In this situation, 'learner-centered education' can be presented as an approach that universities should pursue.

Learner-centered education is a key topic emphasizing the new education paradigm in the $21 \mathrm{st}$ century [4]. It is a concept that embraces the change of the age that needs to respect the needs of learners, who are the consumers of education, away from the existing supplier-centered class management [5-7]. In addition to primary and secondary education, the education of universities needs to shift from the 
existing education methods to the advanced education methods that enable students to create knowledge through creative problem solving led by learners [810]. In the university, team-based learning is drawing attention as a method of education that improves learner-centered competence and engages individual learners in learning, taking into account the situational factors that need to be taught to the majority of students [11-12].

So, we need to study self-directed learning ability, understanding of interpersonal relationships, and satisfaction with the class, focusing on team-based learning, for learner-centered education that college education should pursue. The team-based teaching method is based on self-directed learning that enables students to learn on their own, understanding interpersonal relationships between team members when performing tasks in a team, and learning about the satisfaction of the learner with team-based teaching. We need to study whether it works.

Team-based learning is a structured teaching strategy to maximize the performance of individuals and teams through individual prior learning and interaction between team members in dealing with a problem [13]. Team-based learning is characterized by an educational method that effectively and actively promotes learning through small-group interactions by continuously carrying out team activities and individual learning activities [11]. In South Korea, team-based learning has been studied with a particular focus on nursing and architecture. The previous researches were the effects of team-based learning on interpersonal relationships, problem-solving skills, and knowledge of nursing students [14], effects on problem-solving skills, critical thinking, and selfdirected learning [15], and architectural construction education, team-based learning was applied [16]. Studies have been done to develop a class-based learning strategy course and design model suitable for university classes [17-18], and Kim [19] studied the effects of team-based learning on learners' class interest and academic achievement. Although research on team-based learning has been conducted in various academic fields, domestic research applied to physical-education classes is insufficient. Yoo [20] said that, as a way to strengthen the educational power and competitiveness of Korean college and liberal arts education, it is necessary to reform the curriculum for liberal arts and physical education and to conduct basic research on a consumer-centered liberal-arts education curriculum.
In team-based learning, learners self-directed learning according to their learning goals. It is also a process in which learners evaluate their own learning goals and learn cooperatively. Kim \& Cho [21] reported that learners form a more active attitude of participation than when self-directed learning is a traditional physical education class. Kim [14] reported that the application of team-based learning in nursing education was effective in improving communication skills, problem-solving skills, and self-directed learning skills. In other words, this study aims to verify the relationship between self-directed learning ability, understanding of interpersonal relationships, and satisfaction with the class for classbased participants.

Understanding interpersonal relationships refers to the degree to which team members understand each other by focusing on relationships with team members rather than team tasks in team project activities. Cannon-Bower \& Salas [22] examined in detail the findings that shared cognition among team members had a significant effect on team or organizational performance. According to Cannon-Bower \& Salas [22] and Mathieu, Heffner, Goodwin, \& CannonBowers [23], there were four major categories that team members should share in team activities. These four things are task-specific knowledge, task-related knowledge, knowledge of team members, and shared attitudes and beliefs. When looking at the knowledge of team members, team members need to know each other's preferences, strengths, weaknesses, and tendencies in order to maximize team performance. In other words, if you have knowledge of a team member, first, you can predict and act on how other team members will behave. Second, you can allocate resources according to the team member's expertise and provide necessary information in advance before someone requests it. Last, team members can improve their team's performance by filling in each other's shortages. Knowledge of team members is not a concept that is limited to a specific task, but a type of knowledge that can be used in a wide range of team activities. Druskat and Kayes [24] looked at the effect of team processes on team learning and team performance in short-term project teams and found that team processes consisted of relationship-oriented processes related to team members and task-oriented processes related to tasks. The relationship-oriented process also consists of three sub-variants, all of which are related to relationships with team members during the process of team activity. This is a relationship that affects team learning and team 
performance by forming relationships with other teams as well as members within the team. Understanding the interpersonal relationships, confronting team members who violate discipline, and all the different variables in forming relationships with other teams are all relationship-oriented processes that relate to building relationships with team members. Of these, only the understanding of interpersonal relationships was the variable that had a positive influence on both team learning and team performance. In addition, 'facing a team member who breaks the rules' was not adopted as a research variable, because it was inconsistent with the cultural sentiment of Korea, where it is rare to face other people in public and does not match the short-term team project activity. In addition, the results of relationship with other teams were also found in Druskat and Kaye [24] findings; their influence on team performance was negligible and were excluded because they were inconsistent with the interests of this study. Therefore, this study intends to verify the relationship between self-directed learning ability and satisfaction with the class by setting 'interpersonal understanding' as a main research variable.

The last was satisfaction with the class. Satisfaction with the class refers to the degree to which a learner is satisfied with the learning results, achieves a major goal, and is able to effectively respond to the surrounding environment, and continuously learn as a result of meeting the needs and expectations of students as much as possible. In addition, the student's confidence in the class is continuous [25]. In other words, students' satisfaction with the class is essential for the learning community as well as the successful performance of the school. This is understood as the academic self-efficacy of the student himself. Transformative leadership is based on the vision of the leader, professional competence, professional virtues, and empowerment in the course of instruction between the teacher and students. Such a teacher gains students 'trust, further develops students' abilities, and engages students in active and autonomous class participation. A leadership ability to increase students' satisfaction with the class and ultimately to become a learning community where teachers and students learn on their own [26]. Looking at the concept of satisfaction with the class, Choi defined satisfaction with physical education classes as a subjective feeling or a kind of attitude toward the overall physical education classes at school [27]. Measurement of satisfaction with a physicaleducation class can be attempted in terms of psychological satisfaction, educational satisfaction, social satisfaction, and physical satisfaction, and the important thing is that the negative attitude formed by non-conformity is stronger and more persistent than the positive attitude formed by fitness [27]. Specifically, if you look at the factors of satisfaction, in order to be satisfied with the operation of the class and have it become a satisfying and valuable class activity for participating students, it must be done by teaching methods, careful thinking, and class planning. Also, in the teaching method, it is necessary to teach in a way that suits the individual characteristics and circumstances of the learners, so that effective class instruction and students' satisfaction can be improved. According to Kim, Kwon \& Lee, four variables, teaching method, intention of participation of professors and learners, class content, and class management and communication methods were positive for satisfaction with the class as factors influencing college students' satisfaction with the liberal-arts class [28]. It had a phosphorus effect. In this study, we aim to verify how participants' self-directed learning ability and interpersonal understanding affected the satisfaction with the class in a team-based teaching method.

Therefore, this study aims to study the relationship between self-directed learning ability, understanding of interpersonal relationships, and satisfaction with the class, as the necessity of a new learning method for the 4th Industrial Revolution has emerged as a social issue. In the 4th Industrial Revolution, creative talent approach and resolution, and smooth interpersonal abilities in social life are important factors. In order to cultivate the future talents, the university needs to have learner-centered teaching behavior different from the existing teaching behavior. This study verifies the possibility of fostering future talent suitable for the 4th Industrial Revolution by verifying the relationships between self-directed learning ability, understanding of interpersonal relationships, and satisfaction with the class by applying new learning methods to the field of physical education to foster future-oriented talent. At the same time, the significance of this study is to provide empirical data for the application of team-based learning methods in college education.

\section{Method}

2.1 Measurement 
During the composition of the questionnaire, the measure of self-directed learning ability was developed by Lee [29] and modified and supplemented in the study of the fixed length [30]. Interpersonal understanding used 11 questions that Kwon [31] translated and used from the team skill tool developed by Marshall [32]. Items developed by satisfaction with the class by Ragheb and Bead [34] and survey questions used in the study of $\operatorname{Im}$ [34] were used. The questions of each study variable were all used on a five-point Likert scale.

\subsection{Validity and Reliability}

Validity and reliability were measured to assess the suitability of the questionnaire used in this study. The content-based test was verified by a total of six people, including three professors majoring in education and three Ph.D.s in education engineering. A positive factor analysis was then done. Among the various compliance indices, TLI presented by CFI, Bentler \& Bonett [35], and RMSEA presented by Jorekog and Sorbom [36] were applied as conformity indices. The CFI and TLI were not more than .8 to 9 , and RMSEA was less than .09 [37]. Results of a positive analysis of this study's variable of self-directed learning ability were TLI .943, CFI .955, and RMSEA. 068. In the results of positive factors analysis of satisfaction with the class, the comparable figures were .TLI 953, CFI .967 and RMSEA .069. So the questionnaire has been identified as meeting the criteria for suitability of this model. Interpersonal interest factors are a single factor, and no positive factor analysis was done $<$ Table $1>$.

The Cronbach's $\alpha$ coefficient was analyzed to verify the reliability of this study variable. The selfdirected learning ability was learning support .890; learning motive .933; meta-cognition .871; achievement motivation .921; autonomous learning dictionary .869 , and overall reliability is .895 . Interpersonal understanding turned out to be 956 . Satisfaction with the class level was educational .905; Social .940; physical .779; psychological .917; environmental .866; restful .930 , and overall

Table 1 : The result of validity verification

\begin{tabular}{|c|c|c|c|c|}
\hline Study Tools & $\mathbf{X}^{\mathbf{2}} / \mathbf{d f}$ & CFI & TLI & RMSEA \\
\hline $\begin{array}{c}\text { Self-directed } \\
\text { learning ability }\end{array}$ & 2.900 & .955 & .943 & .068 \\
\hline $\begin{array}{c}\text { Class } \\
\text { satisfaction }\end{array}$ & 2.926 & .967 & .953 & .069 \\
\hline
\end{tabular}

Table 2 : The result of reliability verification

\begin{tabular}{|c|c|c|}
\hline Factors & Sub-factors & Cronbach's $\alpha$ \\
\hline \multirow{4}{*}{$\begin{array}{l}\text { Self-directed } \\
\text { learning ability }\end{array}$} & Learning motive & .933 \\
\hline & Meta-gee & .871 \\
\hline & Achievement period & .921 \\
\hline & $\begin{array}{l}\text { Autonomous } \\
\text { learning dictionary }\end{array}$ & .869 \\
\hline $\begin{array}{l}\text { Interpersonal } \\
\text { understand }\end{array}$ & - & .956 \\
\hline \multirow{6}{*}{ Class satisfaction } & Educational & .905 \\
\hline & Social & .940 \\
\hline & Physical & .779 \\
\hline & Psychological & .917 \\
\hline & Environmental & .866 \\
\hline & Restful & .930 \\
\hline
\end{tabular}

reliability was shown at $.968<$ Table $2>$.

\subsection{Data processing}

The data processing of this study was done using SPSS 21.0 for PASW, frequency analysis of the demographic characteristics of the study subjects, reliability analysis of research variables, and correlation analysis between research variables. A positive factor analysis of the study variables was done using AMOS 18.0. A structural equation model was implemented to analyze the subjects of this study: self-directed learning ability, interpersonal understanding, and their relationship with satisfaction with the class.

\section{Result}

\subsection{The Study Subjects}

The subjects of this study were selected by a teambased liberal arts student at University in South Korea at 2019. The extraction method of the subjects used the expedient sampling method among the nonprobabilistic sampling methods. The survey was selfassessment based on the survey method, and a total of 450 questionnaires were distributed. The analysis of the demographic variables of the study found that there were 269 men (65.8 percent) and 140 women 
(34.2 percent). By grade, 104 students (25.4 percent), 108 (26.4 percent), 117 students ( 28.6 percent) and 80 students (16.6 percent) were in the third year. The number of team-based classes was 229 (56.0 percent) in the first inning, 55 (13.4 percent) in the second, 16 (3.9 percent) in the third, and 109 (26.7 percent) in the fourth or more $<$ Table $3>$.

Table 3 : The result of study subjects

\begin{tabular}{|l|c|c|c|}
\hline \multicolumn{2}{|c|}{ D emographic } & N & $\%$ \\
\hline \multirow{4}{*}{ Gender } & M ale & 269 & 65.8 \\
\cline { 2 - 4 } & Female & 140 & 34.2 \\
\hline \multirow{4}{*}{ Grade } & First & 104 & 25.4 \\
\cline { 2 - 4 } & Second & 108 & 26.4 \\
\cline { 2 - 4 } & Third & 117 & 28.6 \\
\cline { 2 - 4 } & Forth & 80 & 16.6 \\
\hline \multirow{7}{*}{ Frequency } & 1 & 229 & 56.0 \\
\cline { 2 - 4 } & 2 & 55 & 13.4 \\
\cline { 2 - 4 } & 3 & 16 & 3.9 \\
\cline { 2 - 4 } & 4 over & 109 & 25.7 \\
\hline
\end{tabular}

\subsection{Correlation}

The results of identifying the correlations between study variables are shown in Table 4. Self-directed learning skills showed a static correlation between understanding interpersonal relationships $(\mathrm{r}=.575)$ and satisfaction with the class $(\mathrm{r}=.584)$. Understanding interpersonal relationships has shown a static correlation with satisfaction with the class $(r=$ .676). Which shows that there is no multi-polarity problem, because the values of all correlation numbers do not exceed 8 .

Table 4 : The result of correlation

\begin{tabular}{|c|c|c|c|}
\hline & 1 & 2 & 3 \\
\hline $\begin{array}{c}\text { Self-directed } \\
\text { learning ability }\end{array}$ & 1 & 1 & \\
\hline $\begin{array}{c}\text { Interpersonal } \\
\text { Understand }\end{array}$ & $.575^{* * *}$ & 1 & 1 \\
\hline $\mathrm{C}_{\text {lass satisfaction }}$ & $.584^{* * *}$ & $.676^{* * *}$ & 1 \\
\hline
\end{tabular}

$* \mathrm{p}<.05, * * \mathrm{p}<.01, * * * \mathrm{p}<.001$

\subsection{The result of study hypothesis and model fit}

The suitability and hypothesis analysis results of the model in this study are presented in Table 5. First, if you look at the fitness index of the research model, $\mathrm{CFI}=.961, \mathrm{TLI}=.949$, and $\mathrm{RMSEA}=.068<$ Table $5>$. The results of testing the hypothesis of this study are given in Table 4. The first hypothesis was that selfdirected learning affected interpersonal understanding $(\beta=.460, \mathrm{t}=10.829, \mathrm{p}<.001)$. The second hypothesis was that self-directed learning ability had an effect on satisfaction with the class $(\beta=$ $.176, \mathrm{t}=4.563, \mathrm{p}<.001)$. The third hypothesis was that interpersonal understanding affected satisfaction with the class $(\beta=.473, \mathrm{t}=10.773, \mathrm{p}<.001)<$ Table $6>$.

Table 5: The result of verification of model fit

\begin{tabular}{|c|c|c|c|c|}
\hline & $\mathbf{X}^{2} / \mathbf{d f}$ & CFI & TLI & RMSEA \\
\hline Model fit & 2.914 & .961 & .949 & .068 \\
\hline
\end{tabular}

Table 6 : The result of verification of study hypothesis.

\begin{tabular}{|c|c|c|c|c|}
\hline Hypothesis & Estimate & S.E. & C.R & \\
\hline $\begin{array}{c}\text { Self-directed learning ability } \\
->\text { Interpersonal understanding }\end{array}$ & .460 & 042 & $10.829 * * *$ & Accept \\
\hline $\begin{array}{c}\text { Self-directed learning ability } \\
->\text { Class satisfaction }\end{array}$ & .437 & 041 & $10.773^{* * *}$ & Accept \\
\hline $\begin{array}{c}\text { Interpersonal understanding } \\
->\text { Class satisfaction }\end{array}$ & .176 & 039 & $4.563^{* * * *}$ & Accept \\
\hline
\end{tabular}

$* \mathrm{p}<.05, * * \mathrm{p}<.01, * * * \mathrm{p}<.001$

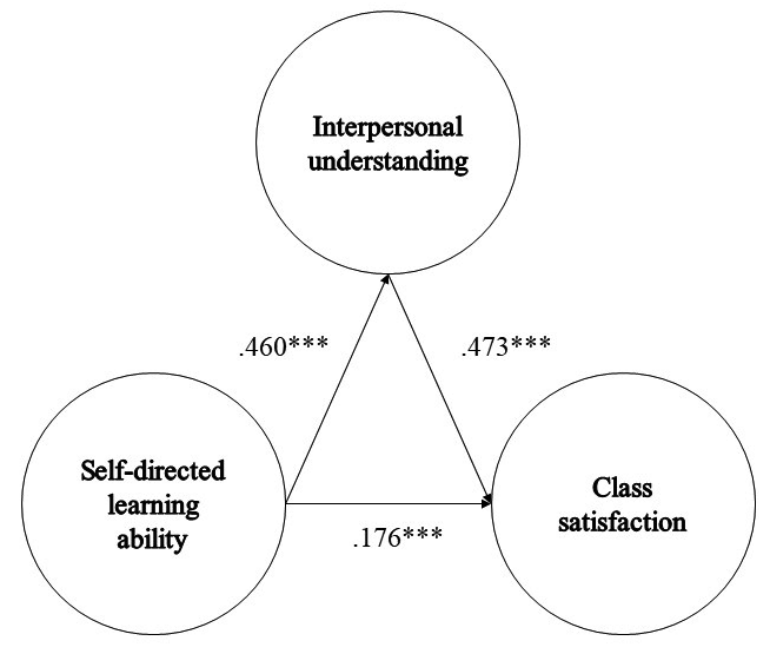

Fig.1 : The result of path analysis verification. 


\section{Discussion}

First, the self-directed learning ability of the participants in team-based liberal-arts sports influenced interpersonal understanding. Unlike teaching classes centered on professors, team-based classes provide a learning environment in which learners can themselves actively participate during team-based learning. Through team-based learning, students are identified as active communicators and mutual cooperators among team members while carrying out team activities and their respective roles. Kim, Im, Jeong [38] and others have said, "The higher the self-reliance, the better the academic performance and the better the interpersonal relationships in schools." It is understandable in terms of the research of Kim, Ha, and Cha [39], and Lim [40], who reported that self-reliance in learning is a factor that has a statistically significant effect on school-life adaptation, including friendship and teacher relationships.

Second, the self-directed learning ability of the team-based class participants affected satisfaction with the class. This means that self-directed learning skills increase satisfaction with classes through active and autonomous participation. Nieder [41] applied the team-based learning method to analyze its effectiveness, showing high satisfaction with the teaching and students' class preparation through the collective class preparation, collective problemsolving process, and improved support for the teambased learning method. These findings support a theoretical view [42-45] that self-directed learning skills play a positive role in building knowledge with other learners rather than just learning by themselves.

Third, the understanding of interpersonal relationships between team-based class participants affected the level of satisfaction with the class. This means that the more team members understand each other and have more knowledge about each other, the more satisfied they are with their classes. Team-based learning has a positive effect on interpersonal relationships, as shown by Moon [46] and Kim [14]'s research. And it shows that the understanding of interpersonal relationships is improved through active promotion of active interaction. In addition, Chang [47] significantly increased the satisfaction with his class through the improvement of students' mutual communication skills and active learning following the application of team-based learning. In this context, team-based learning [48] was a result consistent with prior studies that have an effect on interpersonal relationships and satisfaction with the class [49-50].

\section{Conclusion}

The purpose of this study was to establish the relationship between self-directed learning abilities, interpersonal understanding, and satisfaction with the class by participants in team-based, focused classes. To achieve the purpose of this research, 409 university students who participate in team-based classes at University located in South Korea were selected as candidates for the study. For data processing methods, we did frequency analysis, reliability analysis, and correlation analysis using SPSS 21.0 for Window, and used a structural equation model was done to verify the analysis of confirmatory factors and the theory of research using AMOS 18.0. Following the above research procedure, we arrived at the following research results. First, the self-directed learning ability of the team-based class participants affected interpersonal understanding. Second, the selfdirected learning ability of team-based class participants affected satisfaction with the class. Third, the understanding of interpersonal relationships between team-based class participants affected the level of satisfaction with the class.

As we enter the 4th revolutionary era recently, we are having a great influence on society, organization, and education. Therefore, universities are also trying various methods of education to promote their ability to solve problems in a departure from cramming education [51]. In line with this trend of the times, it is necessary to foster self-directed learning skills that encourage students to learn on their own by introducing team-based classes instead of traditional methods of learning. In addition, it is expected that mutual cooperation among students will be able to cultivate the necessary talent of the future by providing satisfaction level in class for increasing understanding of interpersonal relationships and continuous participation in classes.

\section{Limitation and suggestion of the study}

Suggestions for further study are as follows. First, the subjects of this study have chosen a particular university, so it is rather difficult to expand and interpret our results to all university students. Subsequent studies are expected to produce more accurate research results if the classes are conducted on a team basis after prior consultation by region or 
university. Second, the questionnaire of this study was developed in foreign countries and was translated and used in Korea. We think that appropriate survey tools will be needed for Korean sentiment and culture.

\section{Acknowledgments}

This work was financially supported by Hanseo University Research Support Project in 2020.

\section{References}

1. Ministry of Education, 2021 Basic plan for basic competency diagnosis, Higher Education Policy Division. Seoul, 2019.

2. Park, J., Yu, C. "A Study on the Direction of Physical Education Based on the Changes of School Education in the Future Society." Korean Journal of Sport Pedagogy 24.2 (2017): 1-17.

3. Jung, E. Jung. U. Lee Y. "Proceedings of the Korean Society of Computer Information Conference." The Korean Society of Computer and Information 26.2 (2018): 415-416.

4. Song, I. "Learner-centered paradigm for 21 Century: methods and perspectives." Korean Educational Psychology Association 22.4 (2008): 881-896.

5. Kim, J. "A understanding of the directedness in education." The Korean Society for the Study of Educational Principles 14.1 (2009): 133-173.

6. Min, H. Yu, B., Shim, M. "A study on the factors of best lecture for improving the educational quality of University Teaching." The Journal of Educational Informational and Media 11.3 (2006): 41-66.

7. Catalano, G. D., Catalano, K. C. "Transformation: from teacher-centered to student-centered engineering education." Paper presented at Frontiers in Education Conference, 27th Annual Conference. 'Teaching and Learning in an Era of Change'. Pittsburgh, P.A, USA. November, 1997.

8. Boud, D., Falchikov, N. "Aligning assessment with long-term learning." Assessment \& Evaluation in Higher Education 31.4 (2006): 399-413.
9. Ndebele, C., Maphosa, C. "Exploring the assessment terrain in Higher education: possibilities and threats: A concept paper." Journal of Social Sciences. 35.2 (2013): 149-158.

10. Snowball, J. D., Boughey, C "Understanding student performance in a large class." Innovations in Education and Teaching International 49.2(2012):195-205.

11. Cho, H., Lee, Y. "Investigating conceptual framework on Team-Based Learning for Improving learning process and performance." The Journal of Educational Research 6.2 (2008): $27-42$.

12. Ha, C. Lee, S. "The effects of team based learning model in the elementary science classroom on academic achievement and emotional intelligence." The Journal of Educational Information and Media 20.1 (2014): 1-26.

13. Michaelsen, L. K., Knight A. B., Fink, L. D. "Team-based learning: A transformative use of small groups in college teaching." Sterling, Virginia: Stylus Publishing. 2004.

14. Kim. H. "The effect of team-based learning on nursing students' interpersonal relationships, problem solving skills, and knowledge." Korean Society of Nursing Fall Conference. 2012. 10. p.237.

15. Choi, K., Park, Y. "The effects of team-based learning on problem solving ability, critical thinking disposition and self-directed learning in undergraduate nursing students." Journal of EastWest Nursing Research 20.2 (2014): 154-159.

16. Kim, G., Shin, Y. "Building construction education adopted team-based learning." Journal of the Korea Institute of Building 14.6 (2014): 597-604.

17. Jang, S., Lee, J. "Development of a team-based learning design model in Higher education" Asian Journal of Education 16.1 (2015): 271302.

18. Shim, M. "Team-based learning strategy." Ingenium 16.3 (2009): 57-60.

19. Kim, M. The "assessment targets and assessment 
agents on learners course interest and achievement in team-based learning." Journal of Learner-Centered Curriculum and Instruction 14.11 (2014): 373-392.

20. You, J. "Critique on educational \& competitive power of physical education as liberal education in Korea Higher Education." The Korean Journal of Physical Education 52.6(2013): 205-216.

21. Kim, D., Cho, H. "Analysis in teaching method by contrast between traditional teaching and selfdirected individualized teaching." Korean Journal of Sport Pedagogy 10.1 (2003): 113-128.

22. Cannon-Bower J. A., Salas, E. "Reflection on shared cognition." Journal of Organizational Behavior 22. (2001): 195-202.

23. Mathieu, J. E.; Heffner, T. S.; Goodwin, G. F.; Salas E.; Cannon-Bowers, J. A. "The influence of shared mental models on team process and performance." Journal of applied psychology 85.2(2000): 273-283.

24. Druskat, V. U., Kayes, D. C. "Learning \& performance in short-term project teams." Small Group Research 31.3 (2000): 328-353.

25. Kim, H. "Satisfaction level of physical education class for Middle/High school students." Unpublished Master Thesis. Korea National University of Education. 2003.

26. Yang, S. "A study on the relation between enjoyment, satisfaction with dance lessons and an intention to continue to learn dance." Unpublished Master Thesis. Sungunkwan University Graduate. 2006.

27. Yun, S. "The effect of student's class satisfaction toward general PE teacher's teaching ability in an inclusive PE environment." The Korean Journal of Physical Education 58.3 (2019): 361-370.

28. Kim, S., Kwon, S., Lee. I. "A factor analysis of satisfaction of action learning-based general arts education." Korean Journal of General Education 7.2(2013): 273-299.

29. Lee, Y. "Validation of self-directed learning perceptional inventory for Middle School
Students." The Korea Contents Society 9.12 (2009): 923-931.

30. Koh, J. "The influence of team project physical education classes on self-direct learning and creative personality." Unpublished Master Thesis. Graduate School of Korea National University of Education.

31. Kwon E., "The correlation among team efficacy, interpersonal understanding, pro-activity in problem solving and team performance" Unpublished Master Thesis. Graduate School of Education. Ewha Womans University 2010.

32. Marshall, L. C. "The relationship between efficacy, teamwork, effort and patient satisfaction." Unpublished Doctoral Thesis. The University of Southern California. May. 31, 2003.

33. Beard, J. G.; Ragheb, M.G. "Measuring leisure satisfaction." Journal of Leisure Research. 12.1 (1980): 20-33.

34. Lim, J. "The effects of course satisfaction of students enrolled in elective physical education courses on their physical self-efficacy and intention to continue with physical exercise." Unpublised Master Thesis. Graduate School of Education. Kyonggi Univesity. 2016.

35. Bentler P. M., Bonett, D. G. "Significance tests and goodness of fit in the analysis of covariance structures." Psychological Bulletin 88.3 (1980): 588-606.

36. Jorekog K. G., Sorbom, D. "A guide to program and applications." SPSS Publications, Chicago. 1989.

37. Hong, S. "The criteria for selecting appropriate fit indices in structural equation modeling and their rationales." Korean Journal of Clinical Psychology 19.1 (2000): 161-177.

38. Kim, S., Yim, H., Chung, I. "Does self-direction in learning influence interpersonal relationships in addition to academic achievement?" Journal of Youth Welfare 17.1 (2015): 305-332.

39. Kim, M., Ha, J., Cha. K. "Academic motivation, multiple intelligence, learning style and 
academic achievement, school adjustment." The Journal of Yeolin Education 14.3 (2006): 57-79.

40. Lim, S. "Investigating low-and high-income group differences in structural model: Effects of democratic parenting attitude on self-regulated learning ability, self-esteem, and school adjustment." Korean Educational Psychology association 27.1 (2013): 125-142.

41. Nieder, G.L.; Parmelee, D.X., Stolfi, A., Hudes P.D. "Team-based learning in a medical gross anatomy and embryology course." Clinical Anatomy 18.(2005):56-63.

42. Cho, D. "The relationship between self-direction in learning and interpersonal skills within teams." Journal of Research in Education 23. (2005): 223-242.

43. Garrison, D. R. "Self-directed learning: Toward a comprehensive model." Adult Education Quarterly 48.1 (1997): 18-33.

44. Lee, M., Yang, A. "Factors influencing to 21st century skill of college student." Asia-Pacific Journal of Educational Management Research 4.2. (2019): 7-14.

45. Moon. H., Kim, D. "The effect of a career group counseling program on career maturity, selfesteem and career maturity for agreeable university students. "Asia-Pacific Journal of Educational Management Research 3.2 (2018):15-22.
46. Moon, D. "Effect of team-based learning on international relationship, self-leadership and learner's participation of nursing students." Journal of Digital Contents society 20.7 (2019): 1373-1380.

47. Chang, W. "The Effects of TBL(Team based learning) on the academic achievements and learning satisfaction of University students." The Korea Contents Society 16.12 (2016): 655-666.

48. Whitley, H. P., Bell, E., Eng, M., Fuentes, D. G., Helms, K. L., Maki, D." Practical team-based learning from planning to implementation." American Journal of Pharmaceutical Education. 79.10 (2015): 1-12.

49. Rezaee, R., Moadeb, N., Shokrpour, N. "Teambased learning: A new approach toward improving education. Acta Medica Iranica 54.10 (2016): 679-683.

50. Wei, L. "Research on the innovation of college students' employment guidance in the age of big data." Asia-Pacific Journal of Educational Management Research 4.2 (2019): 23-32.

51. Ahn, B., Choi, J., Lee, S. "A study on class satisfaction on team-project lesson among University students. Journal of Education and Social Science (JESS), HolyKnight, 1. (2020):16. doi: 10.46410/jess.2020.1.1.01. 